\section{Graduate Student Finalists Compete at 1994 MRS Fall Meeting}

Thirty finalists will compete for the MRS Graduate Student Awards, to be presented on Wednesday evening, November 30 , at the 1994 MRS Fall Meeting in Boston. The winners will be honored at a special ceremony, along with recipients of the 1994 Von Hippel, MRSMedalist, and Turnbull Lectureship awards.

Graduate Student Award Finalists, all authors or co-authors of papers to be presented at the Fall Meeting, were selected on the basis of the quality and thoroughness of their research, the originality and independence of their contributions, and their promise for future achievement in materials research.

During special sessions beginning at 12 noon on Monday, November 28, the finalists will give brief talks explaining their research to a panel of judges who will select the award recipients. Among the judges will be organizers from the symposia in which the finalists are participating, members of the MRS Awards Committee, and other MRS representatives. MRS Fall Meeting participants are also invited to attend.

The following list identifies the finalists, their places of study, the titles of their papers, and the symposium or symposia in which each is participating.

\section{Graduate Student Award Finalists- 1994. MRS Fall Meeting}

Maher S. Amer, Drexel University, "Effect of Temperature on Water Absorption and Interfacial Degradation in Graphite/Epoxy SingleFilament Composites Using Laser Raman Spectroscopy" (Symposium R)

Kristi S. Anseth, University of Colorado, "Structural Evolution of Highly Cross-linked Polymer Networks" (Symposium B1)

Rina Chowdhury, North Carolina State University, "Growth and Defect Morphology in Heteroepitaxial Cu/TiN/Si Structures Produced by Laser Physical Vapor Deposition" (Symposium B1) and "Growth of Diamond Films by CVD on Near Net Shape Fabricated B-SiC/TiC Composites, Synthesized Using SHS" (Symposium M)

Sarah Cullen, University of Cambridge, "HREM Lattice Image Simulations of Circular Cross-Sectional Multishell Carbon Nanotubes" (Symposium G)

Corrine L. Curtis, University of California-San Diego, "Properties of Conducting Polymer Interconnects" (Symposium P)

Rajiv Datta, Rutgers University, "Synthesis and Characterization of Rare-Earth-Doped Sulfide Glasses for Active Fiber Optic Devices" (Symposium Za)

Noa Eizenberg. Tel Aviv University, "Molecular Motion through a Fluctuating Bottleneck" (Symposium N)

Sue Feng, Purdue University, "Growth of Oriented Nanometer Channel Structures on Organic Thin Films" (Symposium S)

Martin Fleuster, Institut für Schicht und Ionentechnik, "Competing Columnar Solid Phase Epitaxy and Random Nucleation and Growth of Erbium Implanted $\mathrm{LiNBO}_{3}{ }^{\prime \prime}$ (Symposium Za)

Rachel S. Goldman, University of California-San Diego, "Effects of Substrate Misorientation on Anisotropic Properties of InGaAs Grown by Molecular Beam Epitaxy" (Symposium D)

Uwe Hessinger, University of Washington, "Kinetic Control in Epitaxial Growth: Chemisorption to Heteroepitaxy to Homoepitaxy in $\mathrm{CaF}_{2} / \mathrm{Si}(111)^{\prime \prime}$ (Symposium D)

Nicola A. Hill, University of California-Berkeley, "Electronic Properties of Si Nanocrystals" (Symposium F) and "Calculation of the Excited State Properties of Semiconductor Nanocrystals" (Symposium Oa)

\section{FULLERENE SCIENCE AND TECHNOLOGY An International and Interdisciplinary Journal}

\section{Editor: T. BRAUUN, Eötvös University Budapest, Hungary}

Fullerene Science and Technology presents original contributions covering all areas of fullerene research. Publishing high-quality papers from all fields of scientific inquiry related to fullerenes, this exciting journal provides a worldwide forum for investigators interested in fundamental and applied fullerene science issues.

Fullerene Science and Technology examines a wide range of timely topics about this third form of carbon, including synthesis, structure, statistical models, new instrumentation and equipment for probing fullerenes, technological uses, materials research, and more!

\section{5}

Volume 3, 6 Numbers

Institutional Rate: $\$ \mathbf{\$ 3 9 5 . 0 0}$ ISSN: 01064-122X

For a complimentary copy, contact the Promotion Department at:

MARCEL DEKKER, INC.

270 Madison Avenue, New York, NY 10016

\section{ORDJR FORM}

Please enter my subscription to Vol. 3,6 Numbers, 1995 at the $\square$ institutional rate of $\$ 395.00 ; \square$ individual rate of $\$ 197.50$. Individual subscriptions must be prepaid in American currency by personal check or credit card. Please add \$3.50 per issue (number) for shipping outside the U.S. For airmail to Europe, add $\$ 5.50$ per issue; to Asia, add $\$ 6.50$ per issue. Canadian customers please add $7 \%$ GST.

Please send me a proforma invoice.

Check enclosed made payable to Marcel Dekker, Ins.

$$
\text { Charge my } \square \text { MasterCard } \square \text { Visa } \sqcup \text { American Express }
$$

Card No. Exp. Date

Signature

Name

Address

City/State/Zip

Mail to: Eridania Perez

Marcel Dekker, Inc.

270 Madison Avenue

New York, NY 10016

(212) 696-9000

FAX (212) 685-4540)
Visit MRS Exhibit Booth No. U112 
Bryan D. Huey, University of Pennsylvania, "Observation and Characterization of Electric Fields at Grain Boundaries" (Symposium C) Pawel Keblinski, Pennsylvania State University, "Morphology and Surface Structure of Thin Films" (Symposium B1) Elaine R. Kleinfeld, Lehigh University, "Solution-Phase Preparation of Nanostructural Multilayers" (Symposium U)

Daniel D. Lee, Massachusetts Institute of Technology, "Local Geometry of Surfactant Monolayers and Surface Ordering in a Microemulsion System" (Symposium BB)

Wu Li, Simon Fraser University, "Lithium Intercalation from Aqueous Solution" (Symposium U)

Melanie P. Lutz, University of CaliforniaBerkeley, "Effect of the Interfacial Transition Zone on the Elastic Modulus of Concrete" (Symposium Vb)

James B. Miller, Carnegie Mellon University, "Effect of Prehydrolysis on the Textural and Catalytic Properties of Titania-Silica Aerogels" (Symposium T)

Guarionex Morales, Boston University, "In Situ Studies of Ordering in FeCo Alloys" (Symposium AA)

Deirdre L. Olynick, University of Illinois at Urbana-Champaign, "In Situ Ultra-HighVacuum Transmission Electron Microscopy Studies of Nanocrystalline Copper" (Symposium Ja)
Jallepally Ravi, North Carolina State University, "Athermal Annealing of Self Ion Implantation Damage in Silicon Via In Situ Photoexcitation" (Symposium ))

V. Ravikumar, Northwestern University, "Electron Spectroscopy and Interferometry of Electroceramic Interfaces" and "Structure of Surfaces and Grain Boundaries in $\mathrm{SrTiO}_{3}{ }^{\prime \prime}$ (Symposium C)

Robert M. Strongin, University of Pennsylvania, "Neutron Scattering Study of $\mathrm{C}_{61} \mathrm{H}_{2}$ " and " $\mathrm{C}_{71} \mathrm{H}_{2}$ Cyclopropanes and Annulenes" (Symposium G)

Sriram Swaminarayan, University of Michigan, "Elastic Properties and Segregation Behavior of Very Thin Binary Films" (Symposium B2) and "Phase Diagram of AuPt Mesoscale Atomic Clusters"

(Symposium N)

Jens von Behren, University of Rochester, "Preparation, Properties and Applications of Free-Standing Porous Silicon Films" (Symposium F)

Boris V. Vuchic, Northwestern University, "Direct Correlation of Transport Properties and Microstructure in $\mathrm{Y}_{1} \mathrm{Ba}_{2} \mathrm{Cu}_{3} \mathrm{O}_{7-\mathrm{x}}$ ThinFilm Grain Boundaries" (Symposium $\mathrm{C}$ ) and "Sputter-Induced $\mathrm{Y}_{1} \mathrm{Ba}_{2} \mathrm{Cu}_{3} \mathrm{O}_{7-x} 45^{\circ}$ [001] Tilt Grain Boundaries on MgO: Transport Properties and Atomic Scale Structure" and "Microstructure of a SuperconductorNormal-Superconductor Josephson Junction" (Symposium H)
Thomas Walther, University of Cambridge, "Detection of Random Alloy Fluctuations in High-Resolution Transmission Electron Micrographs" (Symposium D)

Jianming Wen, Iowa State University, "Surface Diffusion of Large Ag Clusters on $\operatorname{Ag}(100)$ " (Symposium B1)

Mike Wong, University of Illinois at UrbanaChampaign, "Sonochemically Produced Hemoglobin Microbubbles"

(Symposium W2)

MRS

\begin{tabular}{|} 
January 13, 1995 \\
is the Deadline for Submitting \\
Graduate Student Award Applications \\
for the 1995 Miss Spring Meeting. \\
For application forms \\
and information, contact: \\
Anne Wagner \\
Materials Research Society \\
9800 McKnight Road \\
Pittsburgh, PA 15237-6006 \\
Phone: (412) 367-3003 \\
Fax: (412) 367-4373
\end{tabular}

\section{SUBSCRIBE to IEE/INSPEC KEY ABSTRACTS TITLES in Materials and Measurement}

- Key Abstracts in Advanced Materials

- Key Abstracts in Electronic Instrumentation

- Key Abstracts in High-Temperature Superconductors

- Key Abstracts in Measurements in Physics

Each month our Materials and Measurement titles cover topics in superconductors and other advanced materials and all aspects of measuremen and devices in physics and electronics.

Key Abstracts provide details of recently-published papers chosen from leading international journals and conference proceedings. Selection is carefully monitored by IEE/INSPEC's team of qualified subject experts.

\section{SAVE TIME AND MONEY!}

STAY AHEAD OF THE COMPETITION!

ORDER THE KEY ABSTRACTS TITLE(S)

OF YOUR CHOICE TODAY!

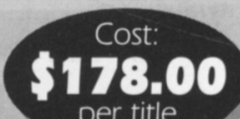

All orders must be prepaid. All subscriptions are on a calendar year basis.

For speedy delivery, mention this code: BMRS94II

IEE, IEEE, AIP, IOP, IERE members

IEE/NSPEC Department

IEEE Service Center

445 Hoes Lane, Piscataway, NJ 08855-1331

Phone: (908) 562-5554 - Fax: (908) 562-8737

All IEE and INSPEC products available in the Americas

through the INSPEC Department of the IEEE.
Just Published by the Materials Research Society

\section{Novel Forms of Carbon II \\ Volume 349 from the \\ 1994 MRS Spring Meeting}

Experts across the broad spectrum of carbon research offer an interdisciplinary look at novel forms of carbon, with extensive coverage given to new results on fullerenes and nanotubes. 81 papers, 557 pages.

ISBN: 1-55899-249-9

Order Code: 349

$\$ 45.00$

MRS Members

$\$ 52.00$

U.S. List

$\$ 60.00$

Foreign

To order...contact the MRS Publications Dept.

Phone: 412-367-3012 or Fax: 412-367-4373 


\section{Place your order today for proceedings of the 1994 MRS Fall Meeting in Boston and SAVE!}

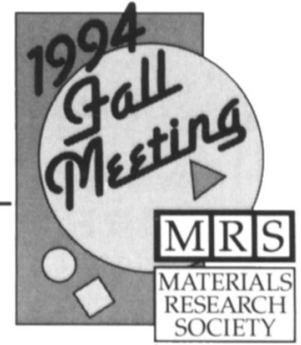

Special pre-meeting prices effective until December 18, 1994. (After that, pay the higher price on the right.)

A: Beam-Solid Interactions for Materials Synthesis and Characterization

Editors: D. E. Luzzi, T.F. Heinz, M. Iwaki, D.C. Jacobson

ISBN: $1-55899-255-3$

$\begin{array}{lll}\$ 60.00 & \$ 67.00 & \text { MRS Member } \\ \$ 67.00 & \$ 75.00 & \text { U.S. List }\end{array}$

$\$ 75.00 \quad \$ 80.00 \quad$ Foreign

B1: Evolution of Thin-Film and Surface

Structure and Morphology

Editors: B.G. Demczyk E.D. Williams, E. Gartunkel, B.M. Clemens, J.E. Cuomo

ISBN: 1-55899-256-1

$\$ 62.00 \quad \$ 69.00 \quad$ MRS Member

$\$ 69.00 \quad \$ 77.00 \quad$ U.S. List

$\$ 77.00 \quad \$ 82.00 \quad$ Foreign

B2: Thin Films: Stresses and Mechanical Properties V

Editors: S.P. Baker, P. Børgesen, P.H. Townsend, C. A. Ross, C.A. Volkert

ISBN: 1-55899-257-X

$\$ 60.00 \$ 67.00 \quad$ MRS Member

$\$ 67.00 \quad \$ 75.00 \quad$ U.S. List

$\$ 75.00 \$ 80.00 \quad$ Foreign

C: Structure and Properties of Interfaces in Ceramics

Editors: D.A. Bonnell, U. Chowdhry. M. Rühle

ISBN: 1-55899-258-8

$\begin{array}{lll}\$ 50.00 & \$ 57.00 & \text { MRS Member } \\ \$ 57.00 & \$ 67.00 & \text { U.S. List }\end{array}$

$\$ 67.00 \quad \$ 72.00 \quad$ Foreign

F: Microcrystalline and Nanocrystalline Semiconductors

Editors: L. Brus, M. Hirose, R.W. Collins, F. Koch, C.C. Tso ISBN: 1-55899-259-6

$\begin{array}{lll}\$ 65.00 & \$ 72.00 & \text { MRS Member } \\ \$ 72,00 & \$ 80.00 & \text { U.S. List }\end{array}$

$\$ 80.00 \$ 85.00$ Foreign

G: Science and Technology of Fullerene Materials

Editors: P. Bernier, T.W. Ebbesen, D.S. Bethune, R.M. Metzger L.Y. Chiang, J.W. Mintmire

ISBN: 1-55899-260-X

$\begin{array}{lll}\$ 55.00 & \$ 62.00 & \text { MRS Member } \\ \$ 62.00 & \$ 70.00 & \text { U.S. List } \\ \$ 70.00 & \$ 75.00 & \text { Foreign }\end{array}$

Code: $359-8$

\section{I1: Materials for Smart Systems}

Editors: S. Troller-McKinstry, K. Uchino, M. Wun-Fogle,

E.P. George, S. Takahashi

ISBN: 1-55899-261-8

$\begin{array}{lll}\$ 50.00 & \$ 57.00 & \text { MRS Member } \\ \$ 57.00 & \$ 67.00 & \text { U.S. List } \\ \$ 67.00 & \$ 72.00 & \text { Foreign }\end{array}$

12: Ferroelectric Thin Films IV

Editors: S.B. Desu, B.A. Tuttle, R. Ramesh, T. Shiosak

ISBN: $1-55899-262-6$

$\begin{array}{lll}\$ 52.00 & \$ 59.00 & \text { MRS Member } \\ \$ 59.00 & \$ 69.00 & \text { U.S. List } \\ \$ 69.00 & \$ 74.00 & \text { Foreign }\end{array}$

$\mathrm{Jb}$ :Grain-Size and Mechanical PropertiesFundamentals and Applications

Editors: N.J. Grant, R.W. Armstrong, M.A. Otooni, T.N. Baker, K. Ishizaki

ISBN: 1-55899-263-4

$\$ 52.00 \quad \$ 59.00$

$\$ 59.00 \quad \$ 69.00$

$\$ 69.00 \quad \$ 74.00$

MRS Member

Code: $362-8$
K: Chemical Vapor Deposition of Refractory Metals and Ceramics III

Editors: W.Y. Lee, B.M. Gallois, M.A. Pickering

ISBN: 1-55899-264-2

$\$ 50.00 \quad \$ 57.00 \quad$ MRS Member

$\$ 57.00 \quad \$ 67.00 \quad$ U.S. List

$\$ 67.00 \quad \$ 72.00 \quad$ Foreign

L: High-Temperature Ordered Intermetallic Alloys-VI

Editors: J. Horton, S. Hanada I. Baker, R.D. Noebe, D. Schwartz ISBN: 1-55899-265-0

$\$ 65.00 \quad \$ 72.00 \quad$ MRS Member

$\$ 72.00 \quad \$ 80.00 \quad$ U.S. List

$\$ 80.00 \quad \$ 85.00 \quad$ Foreign

M: Ceramic Matrix Composites-Advanced High-Temperature Structural Materials

Editors: R.A. Lowden, J.R. Hellmann, M.K. Ferber, S.G. DiPietro, K.K. Chawla

ISBN: 1-55899-266-9

$\$ 50.00 \quad \$ 57.00 \quad$ MRS Membe

$\$ 57.00 \quad \$ 67.00 \quad$ U.S. List

$\$ 67.00 \quad \$ 72,00 \quad$ Foreign

$\mathrm{N}$ : Dynamics in Small Confining Systems

Editors: J.M. Drake, S.M. Troian, J. Kiafter, R. Kopelman ISBN: 1-55899-267-7

$\begin{array}{lll}\$ 52.00 & \$ 59,00 & \text { MRS Member } \\ \$ 59.00 & \$ 69.00 & \text { U.S. List }\end{array}$

$\$ 69.00 \$ 74.00$ Foreign

$P$ : Fractal Aspects of Materials

Editors: Fereydoon Family, B. Sapoval, P. Meakin, R. Woo ISBN: 1-55899-268-5

$\begin{array}{lll} & \\ \$ 55.00 & \$ 62.00 & \text { MRS Member } \\ \$ 62.00 & \$ 71.00 & \text { U.S. List } \\ \$ 71.00 & \$ 76.00 & \text { Foreign }\end{array}$

$\$ 71.00 \quad \$ 76.00 \quad$ Foreign

T: Synthesis and Properties of Advanced Catalytic Materials

Editors: E. Iglesia, P. Lednor, D. Nagaki, L. Thompson

ISBN: 1-55899-270-7

$\begin{array}{lll}\$ 50.00 & \$ 57.00 & \text { MRS Membe } \\ \$ 57.00 & \$ 67.00 & \text { U.S. List }\end{array}$

$\begin{array}{lll}\$ 57.00 & \$ 67.00 & \text { U.S. List } \\ \$ 67.00 & \$ 7200 & \text { Foreign }\end{array}$

\section{U: Solid State Ionics}

Editors: G-A. Nazri, J-M. Tarascon, M. Schreiber

ISBN: 1-55899-271-5

$\begin{array}{lll}\$ 60.00 & \$ 67.00 & \text { MRS Member } \\ \$ 67.00 & \$ 7.00 & \text { U.S. List }\end{array}$

$\$ 77.00 \$ 82.00 \quad$ Foreign

$\mathrm{Va} / \mathrm{Vb}$ : Microstructure of Cement-Based Systems / Bonding and Interfaces in Cementitious Materials

Editors: S. Diamond, F.P.Glasser, L.D. Wakeley / S. Mindess,

J. Skalny, L. Roberts

ISBN: 1-55899-272-3

$\begin{array}{lll}\$ 50.00 & \$ 57.00 & \text { MRS Member } \\ \$ 57.00 & \$ 67.00 & \text { U.S. List } \\ \$ 67.00 & \$ 72.00 & \text { Foreign }\end{array}$

Code: $370-B$

$\$ 67.00$

W1: Advances in Porous Materials

Editors: S. Komarneni, D.M. Smith, J.S. Beck

ISBN: 1-55899-273-1

$\begin{array}{lll}\$ 50.00 & \$ 57.00 & \text { MRS Member } \\ \$ 57.00 & \$ 67.00 & \text { U.S. Llst }\end{array}$

$\$ 67.00 \quad \$ 72.00 \quad$ Foreign
W2: Hollow and Solid Spheres and

Microspheres-Science and Technology

Associated With Their Fabrication and

Application

Editors: M. Berg, T. Bernat, D.L. Wilcox, Sr, J.K. Cochran, Jr.

D. Kellerman

ISBN: 1-55899-274-X

$\begin{array}{lll}\$ 55.00 & \$ 62.00 & \text { MRS Member } \\ \$ 62.00 & \$ 71.00 & \text { U.S. List } \\ \$ 71.00 & \$ 76.00 & \text { Foreign }\end{array}$

Code: 372-B

$\$ 71.00 \$ 76.00$ Foreign

Y: Microstructure of Irradiated Materials

Editors: I.M. Robertson, S.J. Zinkle. L.E. Rehn, W.J. Phythian

ISBN: 7-55899-275-8

$\begin{array}{lrl}\$ 55.00 & \$ 62.00 & \text { MRS Member } \\ \$ 62.00 & \$ 71.00 & \text { U.S. List }\end{array}$

$\$ 71.00 \$ 76.00$ Foreign

Zb: Materials for Optical Limiting

Editors: R. Crane, K. Lewis, E.V. Stryland, M. Khoshnevisan

ISBN: 1-55899-276-6

$\begin{array}{lll}\$ 55.00 & \$ 62.00 & \text { MRS Member } \\ \$ 62.00 & \$ 71.00 & \text { U.S. List }\end{array}$

$\$ 71.00 \quad \$ 76.00 \quad$ Foreign

AA: Applications of Synchrotron Radiation Techniques to Maferials Science

Editors: D.L Perry N Shinn K D'Amico, G. Ice L Termine

ISBN: 1-55899-277-4 Code' 375-B $\$ 52.00 \$ \$ 59,00 \quad$ MRS Member

$\$ 59.00 \quad \$ 69.00 \quad$ U.S. List

$\$ 69.00 \quad \$ 74.00$ Foreign

BB: Neutron Scattering in Materials Science

Editors: D.A. Neumann, T.P. Russell, B.J. Wuensch

ISBN: 1-55899-278-2

$\$ 60.00 \quad \$ 67.00$
$\$ 78$

$\$ 67.00 \quad \$ 77.00$ U.S. List

$\$ 77.00 \$ 82.00$ Foreign

Code: $376-8$

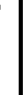

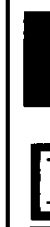

\begin{tabular}{|c|c|}
\hline $\mathrm{M} R$ & $\begin{array}{l}\text { Materials Research Society } \\
9800 \text { MCKniaht Rogd }\end{array}$ \\
\hline $\begin{array}{l}\text { MATERIALS } \\
\text { RESEARCH } \\
\text { SOCIETY }\end{array}$ & $\begin{array}{l}\text { Pittsburgh, PA } 15237 \\
\text { Phone: } 412-367-3012 \\
\text { Fax: } 412-367-4373\end{array}$ \\
\hline
\end{tabular}

In Europe, Africa and the Middle East:

Clarke Associates-Europe, Ltd.

Fourth Floor, The Rackhay

Queen Charlotte Street

Bristol BS1 4HJ

ENGLAND

Phone: 0272268864

Fax: 0272226437

\section{These books are scheduled for publication by spring or early summer 1995.}

Standard shipping \& handling charges of $\$ 3$ per book will be added to each order.

Contact MRS for special shipping. 
INTRODUCTION TO SURFACE PHYSICS M. PRUTTON

This textbook offers a succinct introduction to the study of solid surfaces. In addition to presenting an overview of the field's most up-to-date theories, the book covers techniques used to obtain information about the chemical composition, crystallography, and properties of the top few atomic layers of a solid.

1994210 pp.; illus.

paper $\$ 24.95 /$ cloth $\$ 49.95$

\section{INTRODUCTION TO SYNTHETIC POLYMERS}

IAN M. CAMPBELL

This text provides the ideal introduction to polymer science for undergraduates in chemistry, materials science, and related subjects.

(Oxford Chemistry Series)

1994222 pp.; 98 figs.

paper $\$ 23.95$ /cloth $\$ 49.95$

\section{ORGANOCOPPER REAGENTS}

A PRACTICAL APPROACH

EDITED BY R. J. K. TAYLOR

Authored by leading researchers, this essential laboratory manual features clear, practical descriptions of key procedures used in the preparation and application of organocopper reagents.

(Practical Approach Series in Chemistry 1) Dec. 1994320 pp.; 5 photos, 40 illus. paper $\$ 38.95 /$ cloth $\$ 75.00$

\section{INORGANIC MATERIALS CHEMISTRY}

MARK T. Weller

Copiously illustrated and well-organized, this text offers a comprehensive introduction to solid state materials and to the major experimental technique used to study them-powder $X$-ray diffraction.

(Oxford Chemistry Primers 23)

199496 pp.; 123 illus.

paper $\$ 9.95 /$ cloth $\$ 29.95$
Forthcoming in a new edition...

\section{QUASICRYSTALS \\ A PRIMER \\ SECOND EDITION \\ C. JANOT}

From reviews of the first edition: "Janot presents clearly the fundamentals of quasicrystal research....An excellent primer for all who are interested in the fascinating field of quasicrystals." - Nature

(Monographs on the Physics and Chemistry of Materials 50)

Feb. 1995400 pp.; photos, illus.; $\$ 70.00$

\section{ENGINEERING MECHANICS OF COMPOSITE \\ MATERIALS \\ ISAAC M. DANIEL AND ORI ISHAI}

Up-to-date and well-written, this introduction to the mechanics of structural composite materials offers an authoritative survey of the field's most important theories and research results.

1994352 pp.; 200 illus., 52 photos $\$ 45.00$

\section{NON-LINEAR ELASTICITY AND THEORETICAL MECHANICS}

IN HONOUR OF A. E. GREEN

EDITED BY P. M. NAGHDI, A. J. M. SPENCER AND A. H. ENGLAND

Featuring sixteen up-to-date research papers written by his eminent colleagues and friends, this book covers a variety of topics explored by A.E. Green, the great scientist whose contributions to theoretical and applied mechanics remain models in the field.

Nov. 1994288 pp.; 20 illus.; $\$ 70.00$

\section{MICROSTRUCTURES IN ELASTIC MEDIA PRINCIPLES AND COMPUTATIONAL METHODS \\ Nhan Phan-Thien and Sangtae KIM \\ Taking the reader from analytical to computational methods, this monograph describes various strategies for solving deformation problems of particulate solids. \\ 1994256 pp.; 43 photos; $\$ 65.00$}

Now available in paperback!

\section{BAND THEORY OF SOLIDS}

AN INTRODUCTION FROM THE POINT OF VIEW OF SYMMETRY

SIMON L. ALTMANN

This book provides a unique introduction to the band theory of solids from the perspective of group theory. Throughout, it emphasizes the signifcance of symmetry in determining many of the key concepts necessary for exploring the subject.

1991 (paper 1994) 304 pp.; 43 illus. paper $\$ 29.95$

\section{THERMODYNAMIC S OF FLOWING SYSTEMS}

WITH INTERNAL MICROSTRUCTURE ANTONY N. BERIS AND BRIAN J. EDWARDS Comprehensive and accessible, this monograph presents a step-by-step approach to the continuum modeling of flow phenomena exhibited within materials endowed with a complex internal microstructure, such as polymers and liquid crystals.

(Oxford Engineering Science Series 36)

1994704 pp.; 40 illus.; $\$ 95.00$

\section{Forthcoming... \\ CAVITATION AND BUBBLE \\ DYNAMICS \\ Christopher EARLS BRENNEN}

This superb book provides a coherent and unified treatment of the fundamental physical processes involved in bubble dynamics and the phenomenon of cavitation.

(Oxford Engineering Science Series 44) Jan. 1995320 pp.; 36 photos, I I 2 illus.; $\$ 85.00$

\section{ATOMIZATION OF MELTS}

ANDREW J. YULE AND JOHN J. DUNKLEY This unique book authoritatively unifies the science and application of melt atomization methods.

1994424 pp.; 203 illus.; \$105.00 Visit MRS Exhibit
Booth No. U308 


\section{THE PREEMINENT CORE JOURNAL IN MATERIALS SCIENCE...}

Journal of Materials Science (JMS) and Journal of Materials Science Letters

Editor-in-Chief: W. Bonfield, Queen Mary and Westfield College

Now firmly established as the leading sources of $\checkmark$ primary communication for scientists investigating the structure and properties of all engineering materials, these two companion journals present a dynamic forum for international research.

Journal of Materials Science probes the realtionship between structures, properties, and uses of materials with full-length articles while Journal of Material Science Letters presents interdisciplinary perspectives on glasses, polymers, electrical materials, composite materials, and fibres.

Available Separately...

Materials in Medicine Official Publication of the European Society for Biomaterials

Editors: W. Bonfield, Queen Mary and Westfield College and D.F. Williams,

University of Liverpool

Eeatures structure, properties, and applications of natural materials as well as metals, ceramics, polymers, and composites used in orthopedic, maxillo-facial, cardiovascular, neurological, ophthalmic and dental applications.
Visit MRS Exhibit Booth No. U309

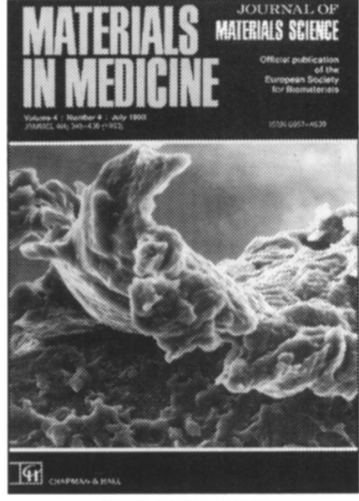

ISSN 0957-4530

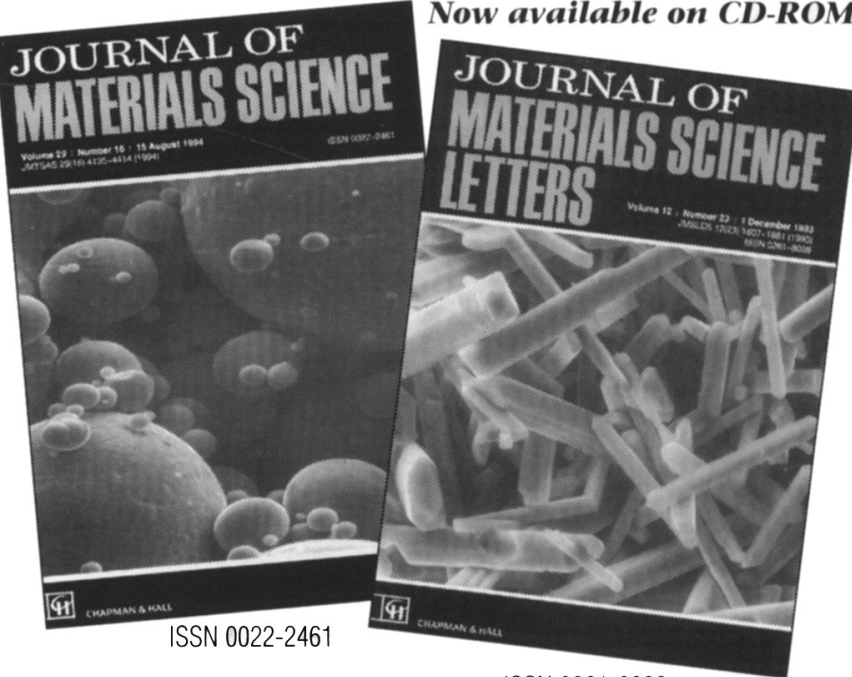

ISSN 0261-8028
Available Separately.

\section{Materials in Electronics}

Editor-in-Chief:

A. Willoughby,

University of Southhampton

overs low dimensional optoelectronics including III-V Compounds, glasses and linear/non-linear crystal materials and lasers, superconductors, conducting polymers, thick film materials, new contact technologies, established electronic device and circuit materials.

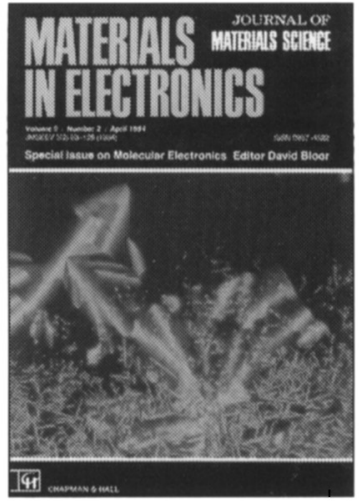

ISSN 0957-4522

Articles indexed by CURRENT CONTENTS-Engineering, Technology, and Applied Sciences,

Science Citation Index, Scisearch, Research Alert, Materials Science Citation Index, Chemical Abstracts, NSPEC, Applied Mechanics Reviews, Chemical Abstracts, AAAS AEROPLUS Database, and Excerpta Medica/EMBASE.

\section{Fill out the order form below for the 1995 archival CD-ROM version. Have your institution or corporate library subscribe NOW..}

Please enter our library's 1995 subscription to

$\square$ JMS (Vol. 30) \& JMS Letters (Vol. 13);

JMS Materials in Medicine (Vol. 13)

and JMS Materials in Electronics (Vol. 7)

(66 issues total): $\$ 3,395.00$

$\square$ JMS Materials in Electronics: $\$ \mathbf{2 7 5 . 0 0}$

$\square$ JMS Materials in Medicine: $\$ \mathbf{4 6 0 . 0 0}$

I $\square$ Please send me (for an additional $10 \%$ of

subscription price) the archival CD-ROM

$\square$ Please send me the 1994 Article Index

I Please return this order form to:

J Journals Marketing Department, Chapman \& Hall $\square$ I have enclosed a check/money order made payable to Chapman \& Hall Journals

Please charge my credit card

$\square$ MasterCard $\square$ VISA $\square$ American Express

Card No

Signature

Exp. Date

Name

Address

City/State/Zip

Personal subscriptions must be prepaid. If paying by credit card, please use billing address. Must have signature if paying by credit card. Prices are subiect to change without notice. Personal subscriptions must be paid by personal check or charge card. 


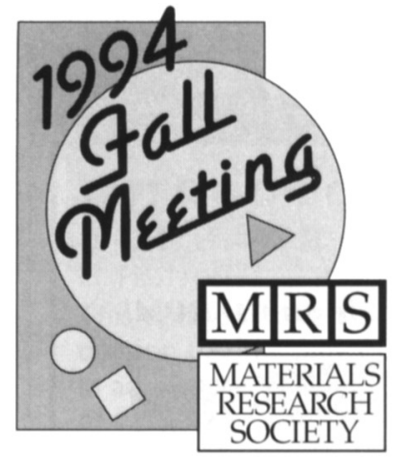

\section{Boston Marriott and Westin Hotel/Copley Place November 29-December 1, 1994}

As part of the 1994 MRS Fall Meeting, a major exhibit will be held to display analytical and processing equipment closely paralleling the nature of the technical symposia. The technical program has been arranged to allow meeting participants ample opportunity to visit the exhibit.

\section{Exhibit Hours}

Tuesday, November 29

Complimentary Reception Tuesday

Wednesday, November 30

Thursday, December 1
Noon to 7 p.m.

.5 p.m. to 7 p.m.

9:00 a.m. to 5 p.m.

9:00 a.m. to 2 p.m.

\section{VISIT THE MRS EXHIBIT...} ...free coffee! ...complimentary reception!

\section{Academic Press}

Advanced Control Systems Corp.

Allied High Tech Products, Inc.

Alpha Aesar/Johnson Matthey

Catalog Co.

American Institute of Physics (AIP)

AIXTRON, Inc.

AJA International

Alcatel Vacuum Products, Inc

AMRAY, Inc.

Anatech, Ltd.

APD Cryogenics, Inc.

Applied Science \& Technology, Inc. (ASTeX)

Bal-Tec Products, Inc.

Balzers

Bio-Logic

Biosym Technologies, Inc.

Blake Industries, Inc.

M. Braun, Inc.

Buehler, Ltd.

Burleigh Instruments, Inc.

Cambridge University Press

Cameca Instruments, Inc.

Ceramaseal

$\mathrm{CHA}$ Industries

Chapman \& Hall

Clarkson University

CoDAS

Commercial Crystal Laboratories

Commonwealth Scientific Corp.

Cooke Corp.

Cressington Scientific

CRYO Industries of America, Inc.

Cryomech, Inc.

Cryostar Associates

Danfysik/GMW

DCA Instruments, Inc

Denton Vacuum, Inc.

\section{Partial List of 1994 Fall Meeting Exhibitors:}

Digital Equipment Corp.

Digital Instruments, Inc.

EastWest Technology Partners, Ltd

Edwards High Vacuum International

Elsevier Science

Emcore Corp.

Evans East

Extrel, Division of Waters

FEI Co.

E.A. Fischione Instruments, Inc.

Fisons Instruments

Gatan, Inc.

Goodfellow Corp.

Gordon \& Breach Publishers

High Voltage Engineering Europa B.V.

Hitachi Scientific Instruments

$\mathrm{Hi}$-Tech Ceramics, Inc.

HK Equipment

Huntington Mechanical Laboratories, Inc.

IBM Analytical Services

Inel, Inc.

Innovative Technology, Inc.

Institute for Scientific Information (ISI)

Instron

Instruments S.A., Inc.

Ion Tech, Inc.

IOP Publishing

Janis Research Co.

JCPDS-ICDD

JEOL USA, Inc.

k-Space Associates

Keithley Instruments

Kimball Physics, Inc.

Kluwer Academic Publishers

Kratos Analytical

Lake Shore Cryotronics, Inc.

Lambda Physik, Inc.

Kurt J. Lesker Co.

Leybold Inficon, Inc.
Los Alamos National Laboratory Luxtron Corp.

Marcel Dekker, Inc.

MDC Vacuum Products Corp.

Microanalysis Group/Oxford Inst.

Microcal Software, Inc.

Microchemistry, Ltd.

Micro Photonics, Inc.

MKS Instruments, Inc.

MMR Technologies, Inc.

Molecular Simulations

MR Semicon, Inc.

MTS Systems Corp.

Nano Instruments, Inc.

Nanophase Technologies

National Electrostatics Corp.

Naval Research Laboratory

Neocera, Inc.

New Focus

Nor-Cal Products, Inc.

North Eastern Analytical Corp.

Omicron Associates

Oxford Applied Research

Oxford Instruments, Inc.

Oxford University Press

Park Scientific Instruments

Peabody Scientific

Philips Electronic Instruments Co.

Physical Electronics

Plasma Sciences, Inc.

Plenum Publishing Corp.

Polysciences

Princeton Gamma-Tech, Inc.

Princeton Instruments, Inc.

Princeton Research Instruments, Inc.

ProChem, Inc.

Pure Tech, Inc.

Quantum Design, Inc.

Radiant Technologies, Inc.
REES Instruments, Inc.

Research \& PVD Materials Corp.

RHK Technology, Inc.

Rigaku/USA, Inc.

Royal Society of Chemistry

Sandia National Laboratories

Schumacher

Scientific Instruments, Inc.

Scintag, Inc.

Semiconductor Processing Co.

Siemens

Skion Corp.

Solid State Equipment Corp.

SOPRA, Inc.

South Bay Technology, Inc

Springer Verlag NY, Inc.

SSC, Inc.

Staib Instrumente

Structure Probe, Inc./SPI Supplies

Superior Vacuum Technology (SVT)

Sycon Instruments, Inc.

Synergistic Technologies, Inc. (STI)

Taylor \& Francis

Technotrade International, Inc

Telemark

Tencor Instruments

Thermionics Laboratory, Inc.

Topsil Semiconductor

TSL, Inc.

Varian Vacuum Products

VAT, Inc.

VCH Publishers, Inc.

Virginia Semiconductor

Voltaix, Inc.

John Wiley \& Sons

J.A. Woollam Co., Inc.

World Scientific Publishing Co.

Carl Zeiss, Inc.

Zygo Corp. 


\section{Scanning Probe Microscopy and Spectroscopy \\ Methods and Applications \\ Roland Wiesendanger}

Introduces the theoretical background of scanning tunneling microscopy, the design and instrumentation of practical STM, and associated systems.

1994 c. 520 pp. $41810-0$ Hardback $\$ 84.95$

42847-5 Paperback $\$ 39.95$

\section{Modern Techniques of Surface Science}

Second Edition

D. P. Woodruff and T. A. Delchar

Describes the physical basis of current techniques in studies of well-characterized solid surfaces. Techniques are grouped according to the underlying physics.

Cambridge Soltd State Science Series

1994604 pp. 41467-9 Hardback \$89.95

42498-4 Paperback $\$ 39.95$

\section{Solid State Electrochemistry}

Edited by Peter G. Bruce

The physical electrochemistry of solids, including the nature of ionic conductivity, the thermodynamics of intercalation reactions, and solid electrolytes and electrodes.

Cbemistry of Solid State Materials 5

1994 c. 300 pp. $40007-4$ Hardback $\$ 64.95$

\section{The Fullerenes}

New Horizons for the Chemistry, Physics and Astrophysics of Carbon

Edited by H. W. Kroto and D. R. M. Walton

Examines the modern study of the chemistry, physics and astrophysics of carbon, through contributions from leading workers in the subject.

Royal Soctety Discussion Volumes

1993152 pp. 45917-6 Paperback $\$ 24.95$

\section{Theory of Magnetic Recording}

\section{H. Neal Bertram}

A fundamental, in-depth look at all the essential features of the magnetic recording process for both high density disk and tape recording

1994364 pp. 44512-4 Hardback \$69.95

$$
\text { 44973-1 Paperback } \$ 34.95
$$

\section{Optical Effects of Ion Implantation}

\section{$P$. D. Townsend, P. J. Chandler and L. Zhang}

Detailed description of the factors and processes that govern the optical properties of ion implanted materials, as well as an overview of the variety of devices that can be produced in this way.

Cambridge Studies in Modern Optics 13

1994294 pp. 39430-9 Hardback \$59.95

\section{Physics and Chemistry of Earth Materials} Alexandra Navrotsky

Surveys the physics and chemistry of earth materials, stressing the fundamental solid state behavior of minerals, and emphasizing both theory and experiment

Cambridge Topics in Mineral Pbysics and Chemtstry 6 1994432 pp. $35894-9$ Paperback $\$ 34.95$

\section{Magnetic Ceramics}

\section{Rau/ Valenzuela}

Overview of relevant aspects of ferrites, including highfrequency transformer cores, permanent magnet cements, microwave telecommunication devices, magnetic recording media and heads.

Cbemistry of Solid State Materials 4

1994 c. 320 pp. $36485-X$ Hardback $\$ 79.95$

\section{Introduction to Lattice Dynamics}

Martin T. Dove

“... a self-contained text that introduces the subject from a basic level and takes the reader on to the research level through applications of the theory to real world situations..." - Micbael D. McCormack, Geopbysics Cambridge Topics in Mineral Pbysics and Cbemistry 4 1993275 pp. 39293-4 Hardback \$54.95

\section{Electronic Structure of Refractory Carbides and Nitrides}

V. A. Gubanov, A. L. Ivanovsky, and V. P. Zhukov Systematic description of the electronic and physico-chemical properties of transition metal carbides and nitrides.

1994270 pp. $41885-2$ Hardback $\$ 79.95$

\section{The Surface Science of Metal Oxides}

Victor E. Henrich and P. A. Cox

Brings together what is currently known about the fundamental properties of metal-oxide surfaces and their interaction with atoms, molecules, and overlayers.

1994478 pp. 44389-X Hardback $\$ 84.95$

\section{Atomic Transport in Solids \\ Alan Allnatt and Alan Lidiard}

Provides the fundamental statistical theory of atomic transport in crystalline solids. Covers lattice defects, non-equilibrium thermodynamics and statistical mechanics. 1994596 pp. 37514-2 Hardback $\$ 135.00$

\section{Excitations in a Bose-Condensed Liquid Allan Griffin}

An up-to-date, systematic account of the microscopic theory of Bose-condensed fluids developed since the late 1950 s. Cambridge Studies in Low Temperature Pbystcs 4

1993320 pp. 43271-5 Hardback \$54.95

Now in paperback...

\section{Spin Glasses}

K. H. Fischer and J. A. Hertz

"A very readable and comprebensive account of the key theoretical concepts and an informed discussion of some important experimental results." -Pbysics Today Cambridge Studies in Magnetism 1 1993418 pp. 44777-1 Paperback \$34.95

\section{Mechanics of Solid Materials}

\section{Jean Lemaitre and J. L. Chaboche}

an excellent book for those needing a comprebensive understanding of the mechanical and thermal behavior of solids."

1994 556 pp. 47758-1 Paperback \$34.95

-Cboice

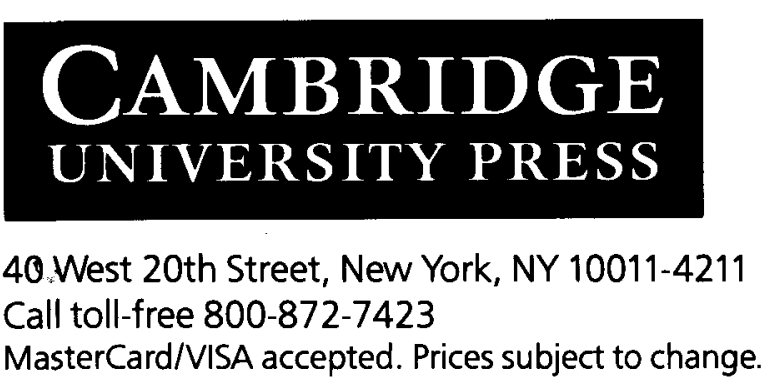




\section{Save $30 \%$ on books from AIP PRESS...}

\section{When you visit the American Institute of Physics booth U306 at the I994 MRS Fall Meeting.}

\section{Statistical Physics of Macromolecules}

Alexander Yu. Grosberg, Russian Academy of Sciences, and Alexei R. Khokhlov, Moscow State University This book offers you a timely and wideranging introduction to this vital area of contemporary physics research. Coverage extends from fundamental concepts to key industrial applications in various fields of polymer physical chemistry and molecular biophysics. Polymers and (omplex Materials series.

\section{AIP Handbook of Modern Sensors}

Jacob Fraden, Thermoscan, Inc.

"Jacob Fraden has produced a valuable, single-volume reference on the devices that bridge the analog and digital worlds. I highly recommend it."-Lawrence G. Rubin, MIT, Physics Today

Obtain, for the first time, descriptions of physical principles, practical designs, and applications of modern sensors for virtually all measurement needs. Nodem histrumentation and Veasurements in Ply sises and Engineering series

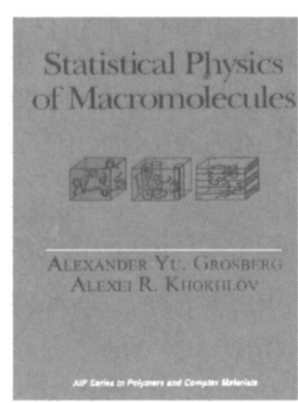

1994, 400 pp., illus. cloth, |-56396-07|-0 List Price $\$ 80.00$ MRS Meeting $\$ 56.00$

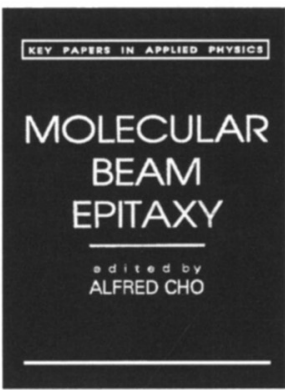

1994, 400 pp, illus.

cloth, I-56396-132-6

List Price $\$ 45.00$

MRS Meeting $\$ 31.50$

\section{Molecular Beam Epitaxy}

Edited by Alfred Y. Cho, AT\&T Bell Laboratories, Murray Hill

This book of key papers papers on molecular beam epitaxy (MBE) is the most comprehensive collection to date on this growing field. The papers highlight work that either began a new area of research or aroused a large population of researchers to follow.

Kiny Papers in, Ipplied Pluysics series

\section{Measurement Errors}

Theory and Practice Semyon Rabinovich

"I suggest that every technical library should own a copy.... Serious experimentalists whose interests are broad will surely want to examine the book with the intent of buying it."Applied Mechanics Review

This book addresses the many and varied problems that physicists and engineers encounter when estimating measurement errors and uncertainty.

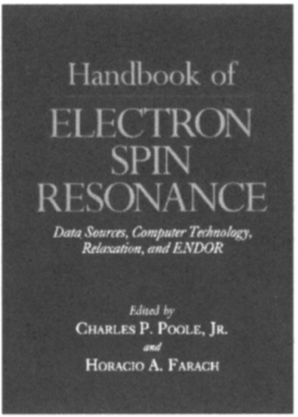

1993, 552 pp., illus. cloth, 1-56396-108-3 List Price $\$ 80.00$ MRS Meeting $\$ 56.00$

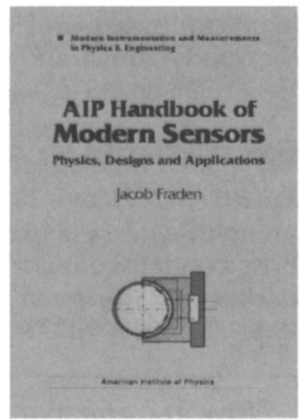

994, 500 pp., illus.

cloth, 1-56396-044-3

List Price $\$ 115.00$

MRS Meeting $\$ 80.50$

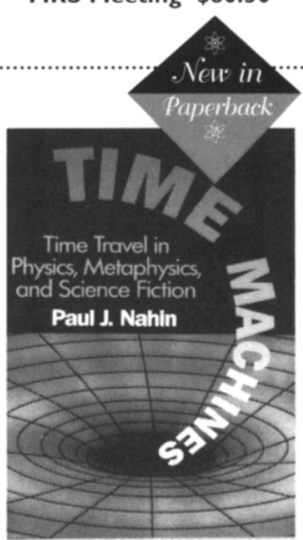

1994, 448 pp., illus. paper, I-56396-37I-X

List Price $\$ 15.95$ MRS Meeting \$11.16

\section{Handbook of Electron Spin Resonance}

Data Sources, Computer Technology, Relaxation, and ENDOR Edited by Charles P. Poole and Horacio A. Farach, University of South Carolina Here's the first book to gather the vast range of experimental data in electron spin resonance (ESR) into a single volume. Concise yet comprehensive, the Handbook offers you an easy-to-use collection of up-todate experimental data, methods and theory.

\section{Time Machines}

Time Travel in Physics, Metaphysics, and Science Fiction Paul J. Nahin, University of New Hampshire "For professional physicists much of the value lies in the extensive technical appendices and footnotes, and the exhaustive list of references. But, if like me, you are a child at heart, the real fun lies in the zany stories and wild speculations."- Physics World

Time Machines takes you on an exhilarating journey through the intriguing theories of scientists and the far-flung imaginations of writers.

\section{To order now, call 800-809-2247.}

Fax: 802-864-7626. Or mail check, MO, or PO (plus $\$ 2.75$ shipping) to: American Institute of Physics, clo AIDC, P.O. Box 20, Williston, VT 05495 For orders outside the U.S. and Canada contact: Oxford University Press, Saxon Way West, Corby Northants NNI8 9 ES, England. Tel.: +44(0)536-454534. Fax: $+44(0) 536-746337$. Note: 30\% Meeting Special applies to book orders taken at show only. 
H. LÜTH, KFA Jülich and RWTH Aachen, Germany

\section{SURFACES AND}

\section{INTERFACES OF SOLIDS}

Second Edition

This comprehensive graduate-level textbook explains simple models and experimental results of interface physics, which underlie much of modern microelectronics. Besides the techniques of preparing well-defined solid surfaces and interfaces, it discusses morphology and structure as well as vibronic and electronic properties, fundamental aspects of adsorption and layer growth. A chapter treats scattering processes, while experimental techniques are presented in separate panels. The text places special emphasis on space-charge layers and heterostructures.

1994/487 PP.. 358 ILLUS., 20 TABS./HARDCOVER $\$ 59.00 / 1$ SBN 0.387-56840-9

R. WIESENDANGER and H.J. GÜNTHERODT, both, University of Basel, Switzerland (eds.)

\section{SCANNING TUNNELING MICROSCOPY I}

General Principles and Applications to Clean and Adsorbate-Covered Surfaces Second Edition

from reviews of the first edition -

"A very useful source for those new to the field and for experts wanting to track down a specific work... The editors have done an excellent job in pulling together and organizing [this] reference." PHYSICS TODAY

This unique introduction addresses the techniques of STM and its applications to metals, semiconductors, layered materials, adsorbed molecules, and superconductors The new edition is updated throughout. Volumes II and III treat electrochemical and biological applications and the theory of STM and related scanning probe techniques. 1994/APPROX. 272 PP., 160 ILLUS./SOFTCOVER $\$ 49.00$ (TENT.)/ISBN 0-387-58415-3 SPRINGER SERIES IN SURFACE SCIENCES, VOL. 20

B. SAPOVAL and C. HERMANN, both, École Polytechnique, Palaiseau, France

\section{PHYSICS OF \\ SEMICONDUCTORS}

This textbook for advanced undergraduates provides not only the fundamental physics of semiconductors, but also insights into the operation of electronic and optical devices composed of semiconductors. The book can be readily adapted to graduate-level courses in condensed matter by coverage of the detailed appendices after most chapters that offer enrichment and extension of material. Also contains numerous applied problems and their solutions.

1994/APPROX. 304 PP., 157 ILLUS., 3 TABS. HARDCOVER/\$49.00/ISBN 0-387-94024-3

\section{A. AUERBACH, Technion, Haifa, Israel \\ INTERACTING ELECTRONS AND QUANTUM MAGNETISM}

This graduate-level textbook emphasizes effects of strong electron interactions in condensed matter. It uses basic models - the Hubbard, Heisenberg and t-J models - to study important concepts: the emergence of magnetism, order and disorder in low dimensions, properties of ground states and low excitations, Haldane's gap and topological Berry phases. These concepts touch such diverse phenomena as the high fractional quantum Hall effect, Kondo systems, superfluidity and superconductivity.

1994/55 PP., 34 ILLUS., /HARDCOVER $\$ 39.95 /$ ISBN 0-387-94286-6

GRADUATE TEXTS IN CONTEMPORARY PHYSICS

J.A.C. BLAND, University of Cambridge, UK, B. HEINRICH, Simon Fraser University, Burnaby, BC, Canada (eds.)

\section{ULTRATHIN MAGNETIC STRUCTURES}

Volume I: An Introduction to the Electronic, Magnetic and Structural Properties

Volume II: Measurement Techniques and Novel Magnetic Properties

The first volume presents comprehensive descriptions of the physical properties, structure, thermodynamic behavior, and methods of studying thin magnetic layers (e.g., spin-polarized electron spectroscopy) from the field's leading experts. The contributions in the second volume treat MBE structures grown on III/V-compound substrates, exchange coupling and magnetoresistance, $\mathrm{RF}$ techniques, magnetic measurements by SMOKE, and more.

Volume I: 1994/APPROX. 366 PP., 130 ILLUS., 9 TABS./HARDCOVER/ $\$ 69.00 /$ ISBN 0 387-57407-7

Volume II: 1994/APPROX. 366 PP., 171 ILLUS., 7 TABS /HARDCOVER/ $\$ 79.00 /$ ISBN 3-540-57687.8

S.M. METEV, Bremen Institute of Beam Technology, Bremen, Germany, and V.P. VEIKo, Institute of Precise Mechanics and Optics, St. Petersburg, Russia

\section{LASER-ASSISTED MICROTECHNOLOGY}

Treats laser applications to a wide variety of problems in microelectronic design and fabrication.

1994/APPROX. 251 PP. 98 ILLUS., 17 TABS HARDCOVER/ $\$ 69.00$ /ISBN 0-387-53925-5 SPRINGER SERIES IN MATERIALS SCIENCE, VOL. 19

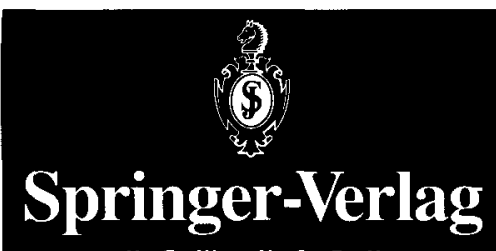

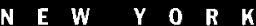

J.F. LUY, Daimler-Benz Forschung, Ulm, and P. RUSSER, Institute for High-Frequency Engineering, Berlin, both, Germany

\section{SILICON-BASED} MILLIMETER-WAVE DEVICES

Describes field-theoretical methods for the design and analysis of planar waveguide structures and antennas. The principles and limitations of transit-time devices with various injection mechanisms, plus aspects of fabrication and characterization and the physical properties of silicon Schottky contacts and diodes, are developed. 1994/APPROX. 360 PP., 202 ILLUS., 14 TABLES HARDCOVER/ $\$ 69.00 /$ ISBN 0-387.58047.6 SPRINGER SERIES IN ELECTRONICS AND PHOTONICS, VOL. 32

K. GRAFF, Telefunken Electronic, Heilbronn, Germany

\section{METAL IMPURITIES IN SILICON DEVICE FABRICATION}

This book provides reliable and up-to-date information on the transition-metal impurities generated during silicon sample and device fabrication. Different contamination mechanisms are discussed and a survey of their impact on device performance is provided. The specific properties of main and rare impurities in silicon are examined. DUE: JANUARY 1995/APPROX. 224 PP./HARDCOVER $\$ 74.00 /$ ISBN 0-387-58317-3

SPRINGER SERIES IN MATERIALS SCIENCE, VOL. 24

J.C. MILLER, Oak Ridge National Laboratory, TN (ed.)

\section{LASER ABLATION}

Principles and Applications

Analyzes experiments and models for the laser ablation of atoms, ions, molecules, and clusters from solid surfaces. Expert contributors address topics such as: the fundamental physics involved; laser ablation and thin-film deposition of high-Tc superconductors; laser ablation of polymers and biological tissues; and more.

1994/APPROX. 199 PP., 85 ILLUS., 6 TABS./HARDCOVER $\$ 59.00 /$ ISBN 0-387-57571-5

SPRINGER SERIES IN MATERIALS SCIENCE, VOL. 28

Three Easy Ways to Order: CALL Toll-Free 1-800-SPRINGER 8:30am to 5:30pm EST (thats $777-4643$ and 201-3484033 in NJ) Please mention S393 when ordering by phone. WRITE to Springer-Verlag New York, Inc., Attn K Quinn/S393, 175 Fifth Avenue, New York. NY 10010. (e-mail:kquinn@springer-ny.com) VISI your local scientific bookstore or urge your libracian to order for your departirge Payment can be made by check, purchase order, or credit card. Please enclose $\$ 2.50$ for shipping ( $\$ 1.00$ each additional book) \& add appropriate sales tax if you reside in CA. IL, MA NJ, NY, PA, TX, VA, and VT. Canadian residents please add $7 \%$ GST.

Remember...your 30-day return privilege is always guaranteed

$10 / 94$ REFERENCE \#: S393 


\section{MATERIALS SCIENCE JOURNALS AND HANDBOOKS... MATERIALS SCIENCE JOURNALS AND HANDBOOKS... MATERIALS SCIENCE}

\section{COMPUTATIONAL MATERIALS SCIENCE}

Editors: U. Landman, School of

Physics, Georgia Institute of

Technology, Atlanta, GA 30332,

USA and R.M. Nieminen,

Laboratory of Physics, Helsinki

Institute of Technology, 02150

Espoo, Finland

AIMS AND SCOPE

Publishes articles of interest to

physicists, chemists and

materials researchers and

engineers and to other scientists

involved with materials

phenomena and computational

modelling.

The journal covers computational modelling of materials properties and phenomena, ranging from the synthesis, characterisation and processing of materials, structures and devices to the numerical methodology of materials simulations. Computer videos and a Free Program

Database are offered to subscribers.

\section{SUBSCRIPTION DATA}

Volumes $3-4$ (in 8 issues)

Price: Dfl. 850.00 (US\$447.00) ISSN 0927-0256

\footnotetext{
For more information contact:

ELSEVIER SCIENCE B.V.

attn. C. Ryan

P.O. Box 103

1000 AC Amsterdam

The Netherlands

Fax: (+31) 205862580

Customers in the USA and Canada: ELSEVIER SCIENCE INC.

attn. J. Weislogel

P.O. Box 882

New York, NY 10159-0945

Fax: (212) 6333680
}

\section{OPTICAL} MATERIALS

An International Journal on the Physics and Chemistry of Optical Materials and their Applications, including Devices

Editor-in-Chief: R.C. Powell, Center for Laser Research, Noble Research Center 413, Oklahoma State University, Stillwater, OK 74078, USA

\section{AIMS AND SCOPE}

The purpose of Optical Materials is to provide a means of communication and technology transfer between researchers who are interested in materials for potential device applications. The journal publishes original papers and review articles on the design, synthesis,

characterisation and applications of optical materials.

\section{SUBSCRIPTION DATA}

Volume 4 (in 6 issues)

Price: Dfl 580.00 (US $\$ 305.00$ )

ISSN 0925-3467

\section{PIEASE VISIT OUR BOOTH AT} THE MRS FALI MEETING WHERE THESE AND OTHER MAJOR PUBLICATIONS WILI BE ON DISPLAY
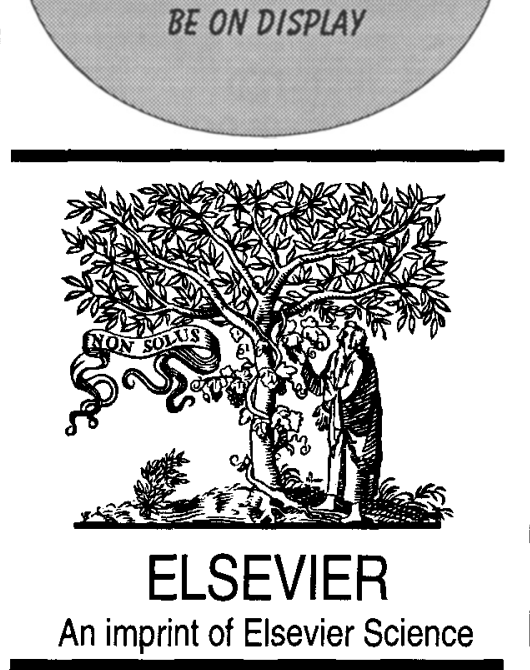

HANDBOOK OF CRYSTAL GROWTH

Edited by D.T.J. Hurle

Volume 1

Fundamentals

A. Thermodynamics and Kinetics

B.Transport Processes and Stability

Volume 2

Bulk Crystal Growth

A. Basic Techniques

B. Growth Mechanisms and Dynamics

Volume 3

Thin Films and Epitaxy

A. Basic Techniques

B. Growth and Dynamics

HANDBOOK ON SEMICONDUCTORS

Completely Revised and

Enlarged Edition

Edited by T.S. Moss

Volume 1

Basic Properties of

Semiconductors

edited by P.T. Landsberg

Volume 2

Optical Properties of Solids edited by M. Balkanski

Volume 3

Materials, Properties and Preparation edited by S. Mahajan

Volume 4

Device Physics

edited by $\mathbf{C}$. Hilsum

FOR COMPLETE DETAILS ON THESE HANDBOOKS PLEASE CONTACT THE PUBLISHER. 
Materials Research Society would like to thank the following for their financial support:

Addax SA

Advanced Energy Industries, Inc.

Advanced Micro Devices, Inc.

Advanced Photovoltaic Systems, Inc.

Aerospace Corp.

AG Associates

Air Products and Chemicals, Inc.

AIXTRON Inc.

Akzo

Allied-Signal, Inc.

Alpha Beta Technology

Aluminum Company of America

Aluminum Research Board

American Xtal Technology

Amoco Oil Co.

AMRAY, Inc.

APD Cryogenics, Inc

APL Engineered Materials, Inc

Applied Materials

ASTeX

Argonne National Laboratory

Asahi Glass Co., Ltd.

AST elektronik GmbH

AT\&T Bell Laboratories

Balzers

BIOSYM Technologies, Inc.

Blake Industries, Inc.

The BOC Group

BP American R\&D

Brookhaven National Laboratory

Butterworth-Heinemann

Cabot Corp.

Cameca Instruments, Inc.

Centre European pour le

Recherche Nucleaire (CERN)

Chemat Technology, Inc.

China Technical Consultants, Inc.

Chorus Corporation

Cober Electronics

Codman \& Shurtleff, Inc.

Coherent Laser Group

Commonwealth Scientific Corp.

Comstock Inc.

Concurrent Technologies Corp.

Conductus Inc.

Consortium für Elektrochemische Ind. $\mathrm{GmbH}$

Corning, Inc.

CREE Research Inc.

CVC Products, Inc.

Dainippon Screen Mfg. Co., Ltd.

DCA Instruments, Inc.

Denton Vacuum, Inc.

Digital Equipment Corp.

Digital Instruments, Inc.

Dow Chemical Co.

Dow Corning Corp.

E.I. duPont de Nemours \& Co., Inc.

EG\&G Idaho Inc.

Electric Power Research Institute (EPRI)

Electricité de France

Elettrorava S.p.A.

Elsevier Science Publishing Co., Inc.

EMCORE Corp.

ENEA

Engelhard Corp.

EniChem America Inc.

Enraf-Nonius Co.

EPI/MBE Products Group

ES Microware

eV Products, division of II-VI

Charles Evans \& Associates
Evans East

Eveready Battery Co., Inc.

Exxon Production Research Co.

Exxon Research and

Engineering $\mathrm{Co}$.

FEl Co.

Fergason Consulting

E.A. Fischione instruments, Inc.

Fisons Instruments

Ford Motor Co.

Fuji Electric Co., Ltd.

Fujitsu Ltd.

Gas Research Institute

GATAN Inc.

Gelest Inc.

General Electric Co.

General Motors Research

Golden Technologies

Goodfellow Corp.

Gordon \& Breach Publishers Inc.

Granville-Phillips Co.

Groupe de Dynamique des

Phase Condenses

Hewlett-Packard Co.

High Voltage Engineering

Europa B.V.

Hitachi Ltd.

Hitachi Scientific Instruments

Hoechst Celanese Research

Division

Howmedica

Hughes Research Laboratories

Huntington Laboratories

IBM AdStaR

IBM Corp.

Institut für Schicht und

Ionentechnik (ISI)

Institute for Scientific Information (ISI)

Institute of Physics Publishing (IOP) Instron Corp.

Instruments SA, Inc./Riber Division

Intel Corp.

Ion Tech, Inc.

JCPDS-International Centre for

Diffraction Data

JEOL USA, Inc.

Johnson Controls, Inc.

Johnson \& Johnson

Johnson \& Johnson Orthopaedics

Kaneka Corp.

Keithley Instruments, Inc.

Kimball Physics, Inc.

Kobe Steel USA, Inc.

Komag Inc.

Kratos Analytical, Inc.

Lake Shore Cryotronics, Inc.

Lambda Physik, Inc.

Lawrence Berkeley Laboratory

Lawrence Livermore National

Laboratory

Kurt J. Lesker Co.

Lightning Optical Corp.

Los Alamos National Laboratory

Magnesium Elektron, Ltd.

Magnet Sales \& Manufacturing Co.

Martin Marietta Energy Systems, Inc.

Materials Research Corp.

MDC Vacuum Products Corp.

MEMC Electronic Materials

MER Corp.

Microwave Materials

Technologies, Inc.

Millipore Corp.
Mitsubishi Electric Corp

Mitsui Engineering \& Shipbuilding

Mitsui Toatsu Chemicals, Inc.

MKS Instruments, Inc.

Morton International

Motorola Phoenix Corporate

Research Laboratories

Motorola APRDL

MR Semicon, Inc.

MV Systems, Inc.

n\&k Technology

Nano Instruments, Inc

Nanophase Technologies

NASA Lewis Research Center

National Electrostatics Corp.

National Semiconductor

NEC Corp.

NEC Research Institute, Inc.

NEOCERA, Inc.

New Focus, Inc.

Newport

Nichia Chemical Industries, Ltd.

Nihon Kessho Koogaku Co., Ltd.

Nippon Oil Corp.

Nippon Steel Corp/Electronics

\& Information Systems

Nissin Electric Co., Ltd.

Nor-Cal Products, Inc.

Norian Corp.

North Eastern Analytical Corp.

Northern Telecom Ltd.

Novapure Corp.

Oak Ridge National Laboratories

OCG Microelectronic Materials Inc

Omicron Associates

OPTOVAC

Park Scientific Instruments

Paterson Instruments PTY Ltd.

Pergamon Press Ltd.

Perseptive Biosystems, Inc.

Philips Electronic Instruments Co.

(PEI)

Physical Electronics

Plenum Publishing Co.

Portland Cement Association

Precision Manufacturing Center

President Enterprises Co.

Princeton Gamma-Tech, Inc.

Pure Tech Inc.

Quantum Design, Inc.

Radiation Monitoring Devices, Inc.

(RMD, Inc.)

Research and PVD Materials

Rexham Industrial

Rigaku/USA Inc.

Rockwell International

Science Center

ROITECH

Sandia National Laboratories

Santa Clara Plastics

Sanyo Electric Co., Ltd.

Schlumberger Doll Research

Schlumberger Well Services

Schumacher/Air Products \&

Chemicals Unit

Science Laboratories, Inc.

Scintag, Inc.

Sematech Inc

SEMICAPS Inc

Semiconductor Processing Co.

SES Research

SFA, Inc.

Sharp Corp.
Siemens Analytical X-Ray

Instruments, Inc.

Siltec Silicon

Solarex Corp

Solid State Equipment Co.

Sony Co., Ltd.

Sopra Inc.

South Bay Technology, Inc.

Spire Corp.

Springer-Verlag New York, Inc.

Staib Instrumente GmbH

Stanford Synchrotron Radiation

Laboratory

Strem Chemicals, Inc.

Submicron Systems, Inc.

Sumitomo Electric USA Inc.

Superior Vacuum Technology inc.

Surface/Interface Inc.

Synergy Research Corp.

Telemark

Tencor Instruments

Texas Instruments, Inc.

Thermionics Laboratory, Inc.

3M Fiber Optics

TN Technologies, Inc.

Tokyo Instruments, Inc.

Topcon Technologies, Inc.

TopoMetrix Corp.

Ultram International

United Solar Systems Corp.

USG Research Center

Vacuum Barrier Corp.

Vacuum Metallurgical Co.

Varian Associates, Inc.

Varian Associates, Inc.

/Continental Electronic Division

VCH Publishers, Inc.

Vertex Pharmaceuticals

Virginia Semiconductors, Inc

Voltaix, Inc.

Vacuum Science Instruments $\mathrm{GmbH}$ (VSI)

John Wiley \& Sons Inc.

Xerox Corp.

Carl Zeiss, Inc.

For more information about the Corporate Participation Program contact:

Mary E. Kaufold

Materials Research Society

9800 McKnight Road

Pittsburgh PA 15237

Phone (412) 367-3036

Fax (412) 367-4373

or

Kenneth E. Voss

Corporate Participation

Committee

Engelhard Corporation

101 Wood Avenue

Iselin NJ 08830-0770

Phone (908) 205-5146

Fax (908) 205-5330 